\title{
Axinella damicornis süngerinden izole edilen sucul bakterilerin proteaz üretkenliklerinin araştırılması ve üretilen proteaz enziminin kısmi karakterizasyonu
}

\section{Investigation of protease productivity of marine bacteria isolated from Axinella damicornis sponge and partial characterization of produced protease}

\author{
Hasan Buğra ÇOBAN ${ }^{1,2}$ (D) \\ ${ }^{1}$ İzmir Uluslararası Biyotıp ve Genom Enstitüsü, Dokuz Eylül Üniversitesi, Sağlık Kampüsü, İzmir, Türkiye \\ ${ }^{2}$ DEÜ Bioİzmir Uluslararası Sağlık Teknolojileri, Geliștirici ve Hızlandırıcı Uygulama ve Araștırma Merkezi, Dokuz Eylül Üniversitesi Sağlık \\ Yerleşkesi, İzmir, Türkiye \\ Sorumlu yazar (Corresponding author): H. B. Çoban, e-posta (e-mail): bugra.coban@deu.edu.tr
}

\section{MAKALE BİLGISİ}

Alınış tarihi 14 Şubat 2020

Düzeltilme tarihi 13 Mart 2020

Kabul tarihi 16 Mart 2020

\section{Anahtar Kelimeler:}

Proteaz

Sucul bakteri

Enzim üretimi

Enzim karakterizasyonu

\begin{abstract}
ÖZ
Proteolitik enzim grubundan proteazlar ticari enzim pazarında önemli bir yere sahiptirler Kullanım alanlarına göre farklı karakteristik özelliklere sahip olmaları istenilen proteazların üstün özellikte olanlarının endüstriye kazandırılması önem teșkil etmektedir. Bu yüzden yeni mikrobiyal türlerin izolasyonu ve bu türlerden üretimlerin yapılması önemli bir çalışma konusudur. Bu çalışmada Kaş, Antalya, Türkiye'den izole edilen 81 sucul bakteriyel izolatın proteaz üretkenlikleri taranmıștır. En üretken izolatın Microbacterium genusuna ait olduğu belirlenmiş ve bu izolat ile çalkalamalı flask üretimlerde $166 \mathrm{U} \mathrm{ml}^{-1}$ aktivitesinde proteaz üretilmiștir. Ayrıca üretilen proteazın optimum sıcaklık ve $\mathrm{pH}$ değerlerinin $35^{\circ} \mathrm{C}$ ve $\mathrm{pH} 8$ olduğu belirlenmiştir. Bunun yanında enzim aktivitesinin $10 \mathrm{mM} \mathrm{MnCl}_{2}$ etkisinde arttı̆̆ ve enzimin uzun süreli depolanmasında $4^{\circ} \mathrm{C}$ 'nin $-20^{\circ} \mathrm{C}$ ve $25^{\circ} \mathrm{C}$ koşullarına göre daha avantajlı olduğu gösterilmiştir.
\end{abstract}

ARTICLE INFO

Received 14 February 2020

Received in revised form 13 March 2020

Accepted 16 March 2020

Keywords:

Protease

Marine bacteria

Enzyme production

Enzyme characterization

\begin{abstract}
Proteases from the proteolytic enzyme group have an important position in the commercia enzyme market. It is crucial to bring the superior properties of the proteases, which are desired to have different characteristics according to their usage, to the industry. Therefore, isolation of new microbial species and enzyme productions from those is a critical study subject. In this study, protease productivity of the 81 bacteria were screened which were isolated from Kas, Antalya, Turkey. It was determined that the most productive strain belongs to the Microbacterium genus, and this strain produced $166 \mathrm{U} \mathrm{ml}^{-1}$ protease activity in shaking flask productions. In addition, the optimum temperature and $\mathrm{pH}$ values of the produced protease were determined to be $35^{\circ} \mathrm{C}$ and $\mathrm{pH} 8$. Also, protease enzyme activity increase under the influence of $10 \mathrm{mM} \mathrm{MnCl} 2$ and $4^{\circ} \mathrm{C}$ condition is more advantageous than of $-20^{\circ} \mathrm{C}$ and $25^{\circ} \mathrm{C}$ in long-term storage of the enzyme.
\end{abstract}

\section{Giriş}

Protein moleküllerinin peptit ve amino asitlere hidrolizini katalizleyen proteaz enzimleri, toplam endüstriyel enzim marketinin yaklaşık \%60'ını kapsamaktadırlar. Proteaz enzimleri gıda, sağlık, deri, ipek, deterjan ve atık su gibi birçok endüstriyel alanda yaygın olarak kullanılmaktadırlar (Fulzele ve ark. 2011; Sharma ve ark. 2017). Bitki ve hayvan kökenli üretimlere nazaran, mikrobiyal proteaz enzimleri üretim ortamlarında daha kısa sürede, daha ucuz șekilde ve büyük miktarlarda elde edilebilmeleri gibi avantajlara sahiptirler
(Sharma ve ark. 2017). Bilimsel çalıșmalarda bakteri, maya ve küf sınıfından birçok mikroorganizma proteaz üretimi için kullanılmış olsalar da Bacillus türleri endüstriyel proteaz üretimlerinde en çok kullanılan türlerdir (Razzaq ve ark. 2019). Örneğin, Novozymes, Solvay Enzymes GmbH ve Amano Pharmaceuticals gibi firmalar Bacillus licheniformis türü başta olmak üzere çeşitli Bacillus türlerinden proteazların üretimini gerçekleştirmektedirler. Üretilen bu proteazlar karakteristik özelliklerine bağlı olarak farklı alanlarda kullanılmaktadırlar. 
İlerleyen biyoteknoloji ile proteaz enzimlerine ve çeşitliklerine olan ihtiyaç ve ilgi giderek artmaktadır. Bu yüzden, doğal ortamlarından izole edilen mikroorganizmalar üzerinde araştırmalar hız kazanmış olup, özel karakterlere sahip enzimlerin keşfedilmesi önemli hale gelmiştir (Fulzele ve ark. 2011). $\mathrm{Bu}$ perspektiften bakilınca, sucul ortam mikroorganizmaları önemlilik taşımaktadır. $\mathrm{Su}$ altı sedimentlerinde bulunan proteince zengin organik maddeleri parçalayarak hücre içi alımına uygun hale getirecek enzimleri sentezleyen bazı mikroorganizmalar yakın zamanda bilimsel çalışmalarda sıkça araştırılmaya başlanmışlardır (Zhang ve ark. 2015).

Bu makalede, Antalya'nın Kaş ilçesinde 24 metre derinlikteki Axinella damicornis süngeri üzerinden izole edilen 81 sucul bakterinin proteaz üretkenliklerinin taranması ve en üretken türden elde edilen proteaz enziminin kısmi karakterizasyonunu gerçekleştirmek amaçlanmıştır.

\section{Materyal ve Yöntem}

\subsection{Bakteri izolatlart}

Daha önce tamamlanan bir TÜBİTAK projesi (SBAG 109S361) kapsamında izole edilen ve saflaştırılarak $-20^{\circ} \mathrm{C}$ 'de stoklanan bakteriler çalışmada kullanılmıştır.

\subsection{Hizlı plaka tarama}

İzole edilen mikroorganizmaların proteaz üretkenliklerinin taranması için hazırlanan hızlı plaka tarama ortam kompozisyonu, litrede $1 \mathrm{~g}$ glikoz, $2 \mathrm{~g} \mathrm{KH}_{2} \mathrm{PO}_{4}, 3$ g et ekstrakt1, $10 \mathrm{~g}$ pepton, $10 \mathrm{~g}$ kazein, $10 \mathrm{~g} \mathrm{NaCl}$ ve $15 \mathrm{~g}$ agar içerecek şekilde hazırlandı. Karışımın $\mathrm{pH}$ değeri derişik $\mathrm{NaOH}$ çözeltisi ile 8'e ayarlanıp $121^{\circ} \mathrm{C}$ 'de 15 dakika otoklavlandı. Besi agar ortamı, steril petri kaplarına dökülerek soğumaya bırakıldı. İzole edilmiş ve dondurularak saklanan 81 adet izolat, buz içerisinde yavaşça çözdürüldükten sonra petri kaplarının yüzeylerine $2 \mu \mathrm{l}$ hacminde nokta inokulasyonu yapıldı. İnoküle edilmiş petriler $30^{\circ} \mathrm{C}$ 'de 24 saat inkübe edildi. Kültivasyon sonrası enzimatik aktiviteden dolayı oluşan proteolitik zon çap1 ve mikrobiyal koloni çapı ölçülerek en yüksek proteolitik kapasiteli izolat daha sonraki çalışmalarda kullanıldı.

\section{3. İzolatın tanımlanması}

En yüksek proteolitik aktivite gösteren izolatın inokulum hazırlama koşullarında kültivasyonu yapıldı. Ardından, Qiagen genomic DNA izolasyon kiti prosedürüne uygun şekilde çoğaltılan hücrelerden genomic DNA elde edildi. Polimeraz Zincir Reaksiyonu (PZR) basamağında 27F (AGAGTTTGATCMTGGCTCAG) ve 1492R (TACGGYTACCTTGTTACGAG) universal primerleri, 16S rRNA dizisini kodlayan gen bölgesini çoğaltmak için kullanıldı. PZR karışımı 10X Taq buffer, $0.2 \mathrm{mM} \mathrm{dNTP,} 0.75 \mathrm{mM} \mathrm{MgCl}_{2}$, $1.25 \mathrm{U}$ Taq polimeraz, $0.4 \mathrm{pmol} \mu^{-1}$ primer ve $150 \mathrm{ng}$ DNA içerecek şekilde toplam $50 \mu \mathrm{l}$ hacimde gerçekleştirildi. Kullanılan PZR programında ön denatürasyon $94^{\circ} \mathrm{C}$ 'de 30 saniye, ardından 30 döngü $94^{\circ} \mathrm{C}^{\prime}$ de 30 saniye, $50^{\circ} \mathrm{C}$ 'de 30 saniye ve $72^{\circ} \mathrm{C}$ 'de 45 saniye olacak şekilde ayarlandı. PZR ürününün $5 \mu$ l'si \%1'lik agaroz jelde yürütülerek kalitesi ve miktarı kontrol edildi. PZR sonrası elde edilen ürünlerin dizileme ve 1000 bootstrap değerli filogenetik ağaç çizimi işlemleri hizmet alımı şeklinde RefGen Biyoteknoloji firmasında yapıldı. Ayrıca, National Center for Biotechnology Information (NCBI) web sayfasinda (http://blast.ncbi.nlm.nih.gov) nükleotid dizi veri bankas1 kullanılarak Basic Local Alignment Search Tool (BLAST) analizi yapıldı ve dizi sisteme kayıtlandı.

\subsection{Inokulum hazırlanması}

İnokulum ortamının kompozisyonu, hızlı plaka tarama yönteminde kullanılan besiyeri ile aynı fakat agarsız ve glikoz miktarı $5 \mathrm{~g} \mathrm{l}^{-1}$ olacak şekilde hazırlandı. Derişik NaOH çözeltisi ile $\mathrm{pH}$ değeri 8 'e ayarlandıktan sonra $250 \mathrm{ml}$ 'lik çalkalamalı flaskta $50 \mathrm{ml}$ hacminde olacak şekilde doldurularak, $121^{\circ} \mathrm{C}$ 'de 15 dakika otoklavlandı. Oda sıcaklığına geldikten sonra, agar ortamında büyütülmüş aktif izolattan $10 \mu$ l'lik öze ile alınan miktar inokulum flaskına transfer edildi. İnokulum flask $130^{\circ} \mathrm{C}$ ve $180 \mathrm{rpm}$ koşullarında 24 saat büyütüldü.

\subsection{Mikrobiyal kültürleme koşulları}

Üretim ortamının kompozisyonu, inokulum ortamı ile aynı tutularak ancak azot:karbon oranını artırmak için glikoz miktarı tekrar $1 \mathrm{~g} \mathrm{l}^{\mathbf{1}}$ olacak şekilde hazırlandı. Derişik NaOH çözeltisi ile $\mathrm{pH}$ değeri 8 'e ayarlandıktan sonra $250 \mathrm{ml}$ 'lik çalkalamalı flaskta $50 \mathrm{ml}$ hacminde, $121^{\circ} \mathrm{C}$ 'de 15 dakika otoklavland. Oda sıcaklığına gelen üretim ortamlarına, inokulum flaskından hacimce $\% 1$ oranında transfer yapılarak başlangıç hücre konsantrasyonu $10^{6}$ hücre $\mathrm{ml}^{-1}$ olacak şekilde standardize edildi. Üretim flaskları, $30^{\circ} \mathrm{C}$ ve $180 \mathrm{rpm}$ koşullarında 48 saat kültürlendi. Günde iki kez $\mathrm{pH}$, hücresel büyüme ve proteaz aktivitelerini ölçmek için örnekler alındı.

\subsection{Mikrobiyal büyüme ölçümü}

Üretim ortamından alınan örneklerin absorbans değerleri, spektrofotometrik olarak $600 \mathrm{~nm}$ dalga boyunda, inokulasyon yapılmamış taze üretim ortamı kör olarak kullanılarak ölçüldü. Ölçülen absorbans değerleri, mikroskop altında yapılan hücre sayımından elde edilerek oluşturulmuş absorbans-hücre sayısı eşitliği kullanılarak hücre sayısı $\mathrm{ml}^{-1}$ birimine çevrildi.

\subsection{Proteaz aktivite ölçümü}

Proteaz aktivite ölçümü Pilanee ve ark. (2008) referansı kısmen modifiye edilerek uygulandı. Üretim ortamından alınan örnekler $\mathrm{pH}$ ve bakteriyal büyüme ölçümleri yapıldıktan sonra dakikada 5500 devir hızında 10 dakika santrifüj edildi. Üstteki sıvı kısımdan alınan $0.5 \mathrm{ml}$ örnek, $2.5 \mathrm{ml}$ ağırlıkça \%0.6'lik kazein içeren fosfat tamponu ( $50 \mathrm{mM}, \mathrm{pH}: 8.0)$ ile karıştırılarak $35^{\circ} \mathrm{C}$ 'de 20 dakika inkübe edildi. Karışımlara $2.5 \mathrm{ml} 0.44 \mathrm{M}$ trikloroasetik asit eklenerek reaksiyon durduruldu ve örnekler oda sıcaklığında 10 dakika bekletildi. Daha sonra örnekler dakikada 5500 devir hızında 10 dakika santrifüj edildi. S1v1 kısımdan alınan $0.25 \mathrm{ml}$ örnek, $1.25 \mathrm{ml} 0.5 \mathrm{M} \mathrm{Na}_{2} \mathrm{CO}_{3}$ ve 0.25 ml Folin-Ciocalteu's fenol sıvısı ile karıştırılarak 30 dakika boyunca oda sıcaklığında ve karanlıkta bekletildi. Absorbans değerleri $600 \mathrm{~nm}$ dalga boyunda ölçülüp, tirozin standardından elde edilen değerler baz alınarak enzimatik aktivite değeri hesapland1. Bir enzim birimi (U), dakikada ve $35^{\circ} \mathrm{C}$ 'de $1 \mu \mathrm{mol}$ tirozin ortaya çıkmasını sağlayacak enzim miktarı olarak tanımland1.

\section{8. Üretilen proteaz enziminin kısmi karakterizasyonu}

Üretilen proteaz enzimi $5-10 \mathrm{pH}$ ve $4-70^{\circ} \mathrm{C}$ sıcaklıkları arasında aktivite ölçümüne tabi tutularak optimum değerler belirlendi. Ayrıca çeşitli kimyasalların (EDTA, $\mathrm{MgSO}_{4}, \mathrm{MnCl}_{2}$, $\mathrm{CaCl}_{2}, \mathrm{ZnSO}_{4}, \mathrm{FeSO}_{4}$ ) $10 \mathrm{mM}$ konsantrasyonlarının enzim aktivitesi üzerine etkileri incelendi. Son olarak, optimum 
koşullarda üretilen proteaz enzimi $-20,4^{\circ} \mathrm{C}$ ve oda sıcaklıklarında bekletilerek aktivite değişim değerleri ölçüldü.

\section{Bulgular ve Tartışma}

$\mathrm{Bu}$ çalışmada izole edilen 81 sucul izolatın proteaz aktiviteleri hızlı plaka tarama yöntemiyle belirlendikten sonra en üretken izolattan üretimler yaparak, enzimin kısmi karakterizasyonu gerçekleştirilmiştir.

\subsection{Hizlı plaka tarama sonucu}

Nokta inokulasyonu ile ekilen izolatların $30^{\circ} \mathrm{C}$ 'de 24 saat kültürlenmesi sonucu oluşan proteolitik zon çapı ve mikrobiyal koloni çapı ölçülerek oranlandı. Taranan izolatlar arasından 17 $\mathrm{mm}$ proteolitik zon çapı ve $3 \mathrm{~mm}$ mikrobiyal koloni çapı ile en yüksek proteolitik aktivite oranı (5.67) gösteren 6.20.3 kodlu izolat ile çalışmalara devam edildi (Şekil 1).

\subsection{Mikrobiyal türün belirlenmesi}

En yüksek proteolitik aktivite gösteren izolat, inokulum hazırlama koşullarında kültürlenerek büyütüldü. Genomik izolasyon, dizi analizi ve sonuçların işlenmesi basamaklarından sonra elde edilen 1000 bootstrap değerli filogenetik ağaçta izolatın Microbacterium genusuna ait olduğu belirlendi (Şekil 2). Ayrıca elde edilen 16S rDNA dizisi NCBI nükleotid veri bankasına MT013395 numarası ile kaydettirildi.

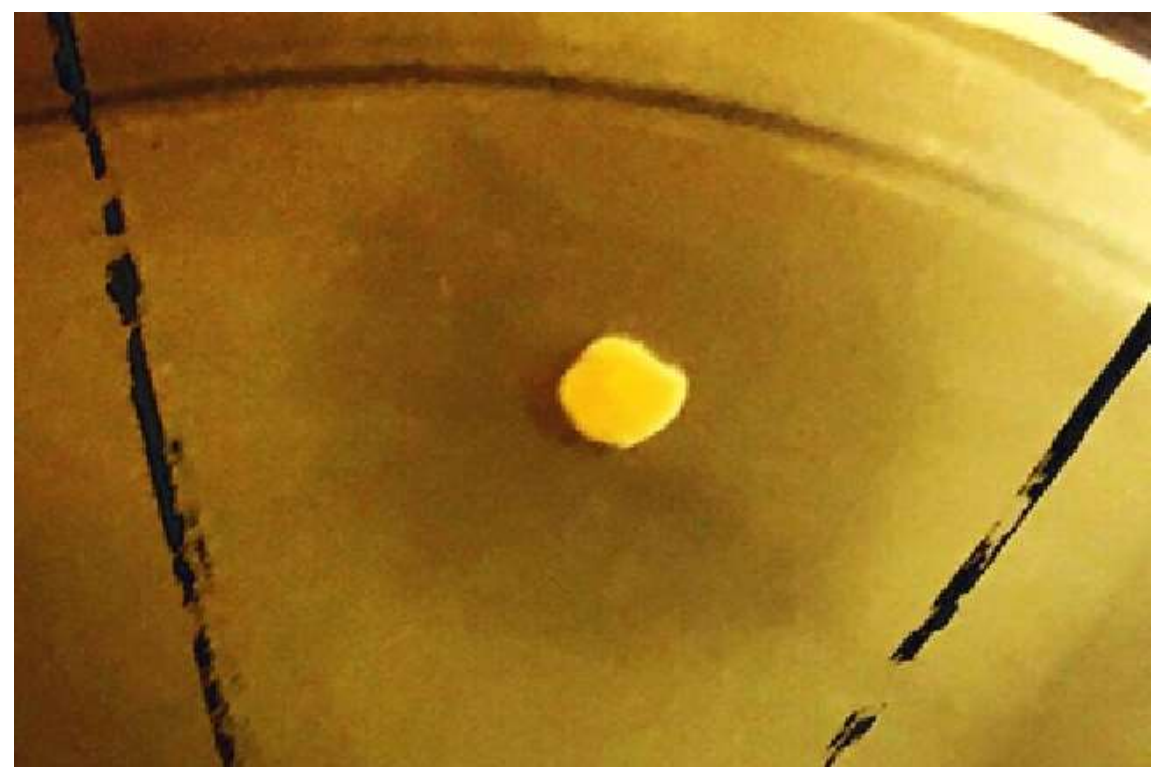

Şekil 1. En yüksek proteolitik aktivite oranı gösteren izolatın petrideki görüntüsü.

Figure 1. The highest proteolitic activity ratio shown specie on petri dish.

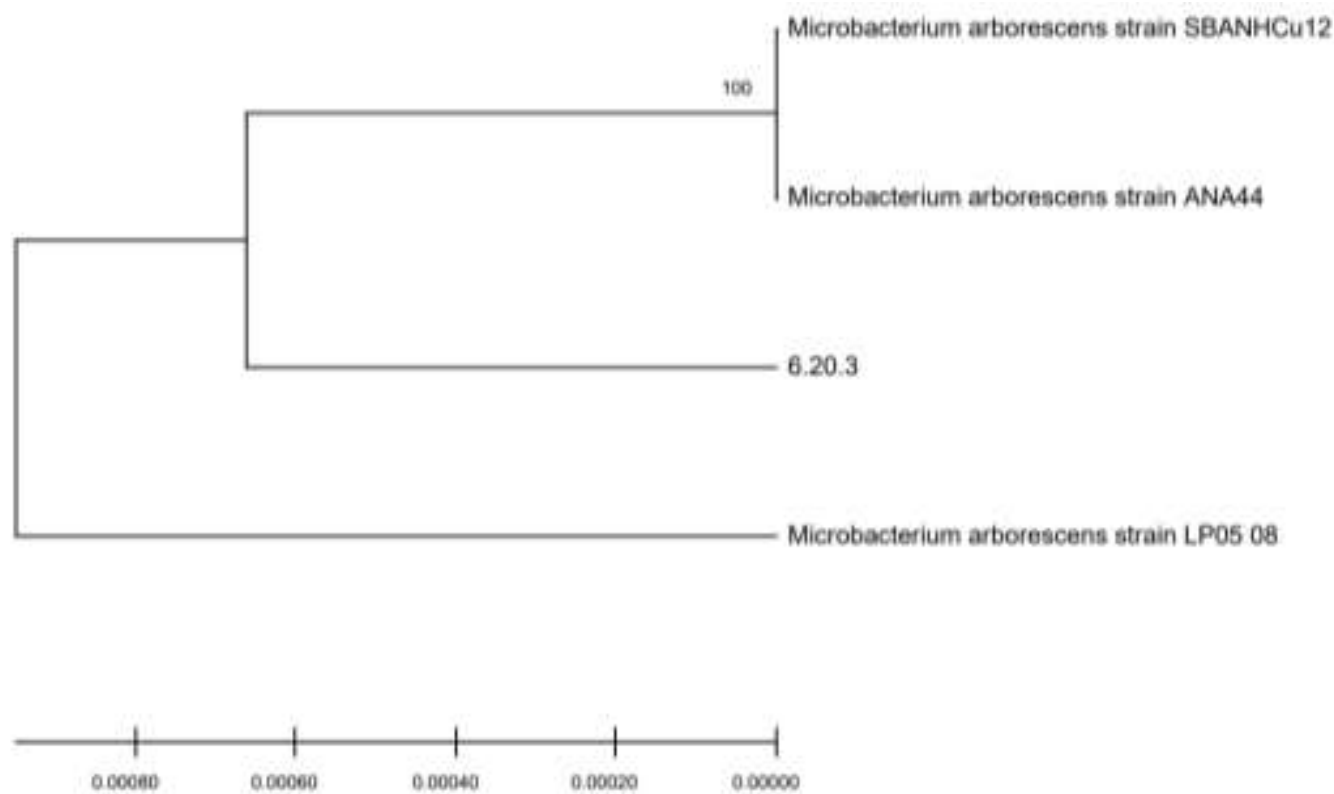

Şekil 2. Seçilen yüksek proteolitik aktivite gösteren izolatın 1000 bootstrap değerli filogenetik ağaç çizelgesi.

Figure 2. 1000 bootstrap philogenetic tree of the highest proteolitic activity shown specie. 


\section{3. Çalkalamalı flask üretimi ve üretim kinetiği}

Şekil 3’te görüldüğü üzere 48 saatlik üretim boyunca $\mathrm{pH}$ değeri 8 ile yaklaşık 7.60 arasında değişlik gösterdi. Üretimin 30. saatinde $\mathrm{pH}$ değeri gözlemlenen en küçük değer olan 7.6 civarında ölçüldü ve 36 . saatte de benzer bir değer okundu. Ancak ilerleyen saatlerde $\mathrm{pH}$ değerinin artarak 48. saatte 7.84 'e kadar ulaştığ 1 gözlemlendi. Bu verilerden üretimin yaklaşık 30 . saatine doğru temel karbon kaynağının mikroorganizma tarafından tüketildiği ve devamında ortamda oluşmuș asitlerin karbon kaynağı olarak kullanılmasıyla $\mathrm{pH}$ değerinin tekrar yükselmeye başladığı söylenebilir (Blommel ve ark. 2007). Proteaz aktivitesi üretimin ise ilk zamanlarından itibaren hizla yükselerek 30. saatte en yüksek değeri olan $166 \mathrm{U} \mathrm{ml}^{-1}$ ulaştı. Devam eden 18 saatlik üretimle beraber proteaz aktivitesinin $\% 12$ azaldığı ölçüldü.

Hücre konsantrasyonu inokulasyon sonrası kisa bir adaptasyon süresinden sonra hızla artarak 36. saatte en yüksek değer 2.27.10 hücre $\mathrm{ml}^{-1}$ konsantrasyonuna ulaştı. Anlık hücresel özgül büyüme hızına $(\mu)$ bakıldığında hücreler üretimin ilk aşamalarında daha hızlı bir şekilde büyümekteyken, bu değer zamanla azalarak 30. saatten itibaren neredeyse sifır değerine ve 42. saatte de negatif değere ulaşt1. Bu değerler yine temel karbon ve enerji kaynağı olan glikozun bitişe geçtiği tahmin edilen sürenin doğruluğunu teyit etmektedir. Birim hücre başına üretim verimi değerine $\left(\mathrm{Y}_{\mathrm{px}^{-1}}\right)$ bakılınca üretimin 12. saatindeki hücrelerin en yüksek üretkenlikte olduğu gözlemlendi. Bu hem hücrelerin aktif şekilde bölündüğü hem de ortamda önceden az miktarda proteaz enzimi bulunmasından dolayı hızlı bir artış değerinin hesaplanmasına bağlanabilir. Ayrıca, proteaz üretim verimliliği açısından en yüksek değer olan $9.59 \mathrm{U} \mathrm{ml}^{-1} \mathrm{~s}^{-1}$ üretimin 24. saatinde ölçüldü. Çizelge 1'den öngörüleceği üzere üretimin, kesikli besleme ve sürekli üretim biyoreaktör dizaynlarına taşınması durumunda kullanılması gereken $\mu$ değerleri hesaplanabilecektir.

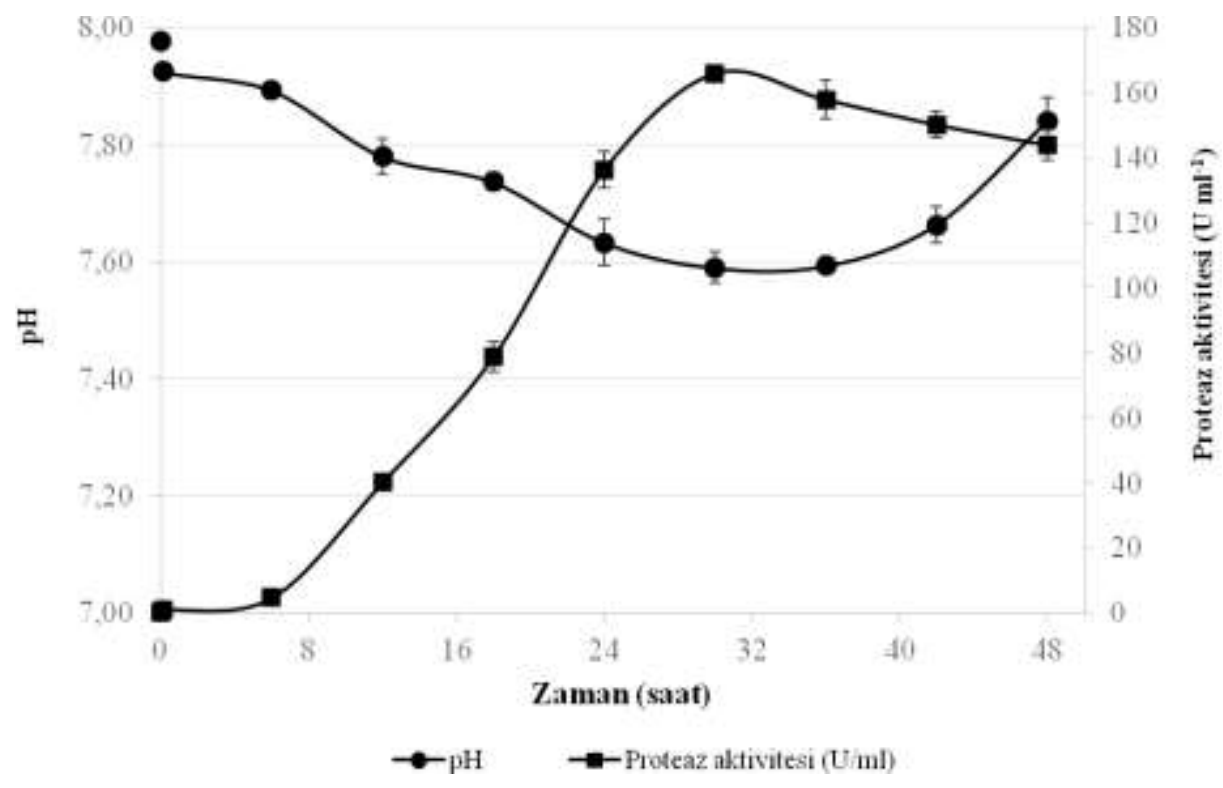

Şekil 3. Mikrobiyal proteaz üretimi sırasındaki pH ve enzim aktivitesi değişimi.

Figure 3. pH and enzyme activity changes during microbial protease production.

Çizelge 1. Mikrobiyal üretimde elde edilen kısmi kinetik parametreler.

Table 1. Partial kinetic parameters obtain from microbial production.

\begin{tabular}{|c|c|c|c|c|}
\hline $\begin{array}{c}\begin{array}{c}\text { Kültürleme süresi } \\
\text { (saat) }\end{array} \\
\end{array}$ & $\begin{array}{l}\text { Hücre konsantrasyonu } \\
\left(\text { hücre } 10^{6} \mathrm{ml}^{-1}\right)\end{array}$ & $\begin{array}{l}\text { Anlık hücresel özgül } \\
\left.\text { büyüme hızı (1 saat }{ }^{-1}\right)\end{array}$ & $\begin{array}{l}\text { Birim hücre başına üretim verimi } \\
\left(\mathbf{Y}_{\mathrm{p} \mathrm{x}}{ }^{-1}\right)\left(\mathrm{U} \mathrm{ml}^{-1} \mathrm{hücre}^{-1} \mathbf{1 0}^{-6}\right)\end{array}$ & $\begin{array}{c}\text { Proteaz üretim verimliliği } \\
\left(\mathrm{U} \mathrm{ml}^{-1} \text { saat }^{-1}\right)\end{array}$ \\
\hline 0 & 0.0 & - & - & - \\
\hline 0.1 & 1.6 & - & - & - \\
\hline 6 & 16.6 & 0.396 & 0.221 & 0.62 \\
\hline 12 & 62.1 & 0.220 & 0.573 & 5.93 \\
\hline 18 & 144.3 & 0.141 & 0.267 & 6.42 \\
\hline 24 & 213.1 & 0.065 & 0.270 & 9.59 \\
\hline 30 & 222.6 & 0.007 & 0.133 & 4.95 \\
\hline 36 & 227.0 & 0.003 & Negatif değer & Negatif değer \\
\hline 42 & 225.8 & Negatif değer & Negatif değer & Negatif değer \\
\hline 48 & 211.6 & Negatif değer & Negatif değer & Negatif değer \\
\hline
\end{tabular}




\section{4. Üretilen proteaz enziminin kısmi karakterizasyonu}

Üretilen proteaz enzimi 5 ile $10 \mathrm{pH}$ değerleri arasında enzim aktivite ölçümüne tabi tutuldu. Enzimatik aktivite ölçümünde kullanılan substrat, kazeinin izoelektrik noktası 4.6 civarında olduğu için en düşük pH 5 değeri incelendi. Şekil 4'te de görüldüğü üzere incelenen aralıkta en yüksek proteaz aktivitesi pH 8'de elde edildi. Enzimin maksimum aktivite değerinin $\mathrm{pH} 5$ ve 10 koşullarında sırasıyla \% 43 ve \% 41 azaldığ 1 gözlemlendi. Bu iki uç değer arasında kalan pH 6 ve 9 arasındaki değerlerde, enzimin aktivitesini büyük ölçüde koruyabildiği sonucu kaydedildi. Asidik proteazlar (optimum pH 3.8-5.6) çoğunlukla küflerden elde edilmekte olup soya sosu içeriği, protein hidrozolatı hazırlama, bira ve meyve suyu berraklaştırma gibi işlemlerde kullanılmaktadırlar. Nötral (optimum pH 5-8) proteazlar ise yine genellikle gıda ve alkol endüstrisinde kullanılmaktadır. Alkalin (optimum pH 9-11) proteazlar ise çoğunlukla bakteriyel türlerden elde edilmekte ve deterjan, deri endüstrilerinde kullanılmaları tercih edilmektedir (Razzaq ve ark. 2019). Optimum $\mathrm{pH}$ değeri 8 olarak ölçülen proteaz enzimin zayıf alkali koşulu sevmesi, hem gıda hem de deterjan ve deri endüstrisinde kullanımını uygun kılmaktadır.

Üretilen proteaz enzimi $4-70^{\circ} \mathrm{C}$ arasında aktivite ölçümüne tabi tutuldu. Enzimin $4^{\circ} \mathrm{C}$ 'de maksimum aktivitesinin \%51'ini gösterebildiği ölçüldü. Artan sıcaklık değeri ile beraber enzim aktivitesi de artarak $35^{\circ} \mathrm{C}$ 'de en yüksek değer elde edildi. Enzim, aktivitesini 40 ve $50^{\circ} \mathrm{C}$ 'de koruyarak sirasiyla $\% 2$ ve $\% 10$ kayıp gösterdi. Ancak 60 ve $70^{\circ} \mathrm{C}$ 'de aktivite kayıları $\% 38$ ve \%84 olarak kaydedildi (Şekil 5). Yine bu sonuçlardan enzimin $10-60^{\circ} \mathrm{C}$ aralığında aktivitesinin $100 \mathrm{U} \mathrm{ml}^{-1}$ ' den fazla olduğu görülmektedir. $\mathrm{Bu}$ geniş sıcaklık aralığında

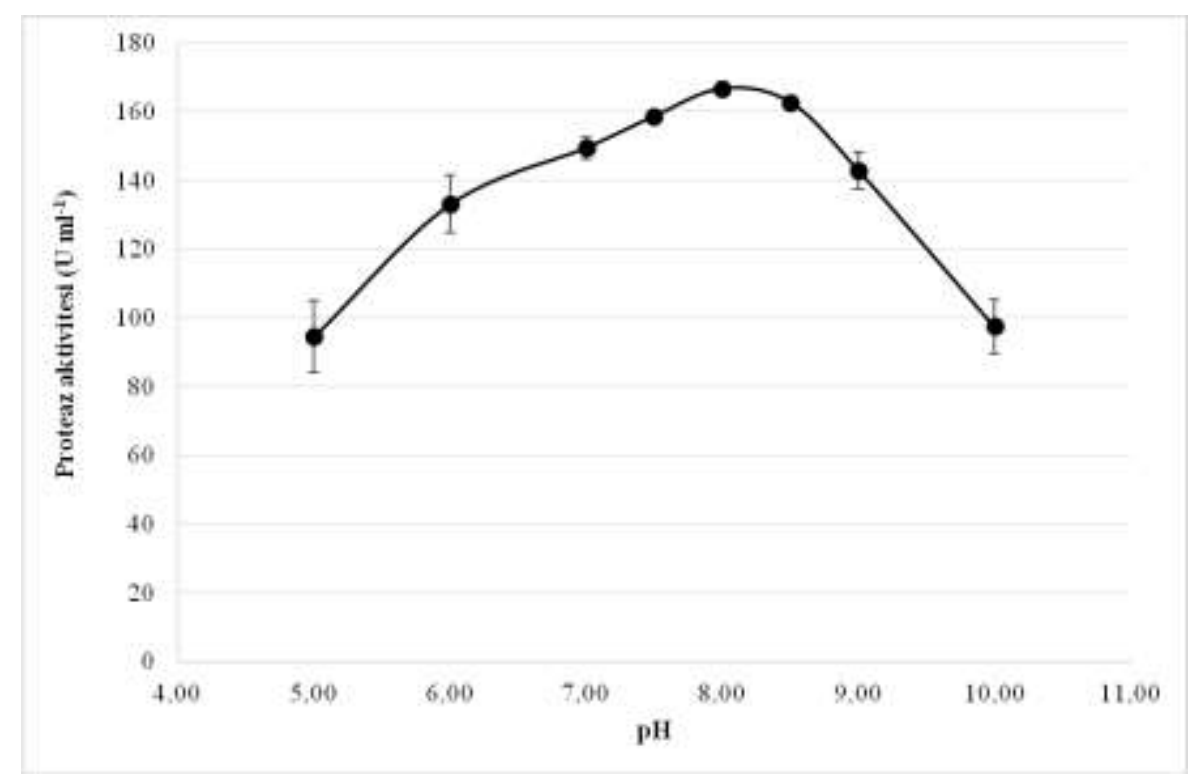

Şekil 4. Proteaz aktivitesinin $\mathrm{pH}$ ile değişimi.

Figure 4. Protease activity changes by $\mathrm{pH}$.

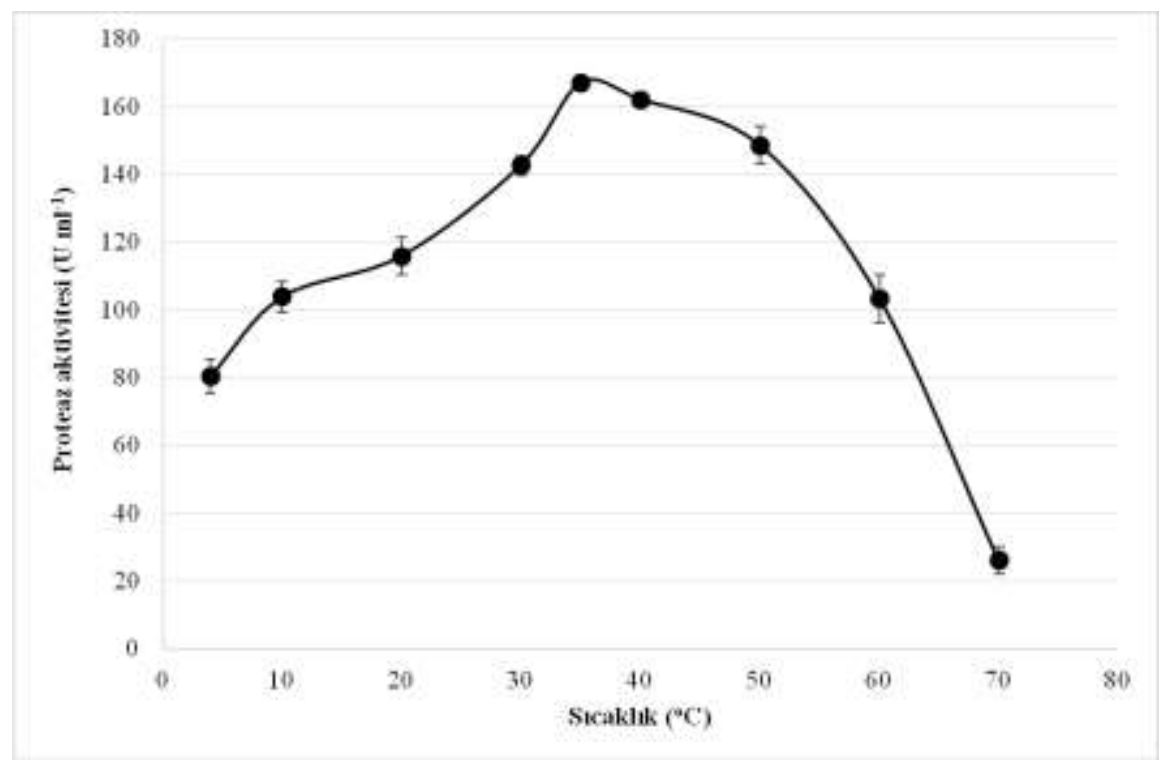

Şekil 5. Proteaz aktivitesinin sıcaklık ile değişimi.

Figure 5. Protease activity changes by temperature. 
çalışabilmesinden dolayı üretilen proteaz enziminin deterjan endüstrisinde kullanılabilecek kuvvetli bir aday olduğu söylenebilir. Literatürdeki çalışmalarda sucul ortamlardan elde edilmiş izolatlardan üretilmiş proteaz enzimlerinin oldukça farklı optimum sicaklık ve $\mathrm{pH}$ değerlerine sahip olduğu görülmüştür. $\mathrm{Bu}$ çalışmaların birinde, Etiyopya'nın Arenguadie alkali soda gölünden izole edilen Microbacterium genusuna ait bir türün ürettiği proteaz enziminin optimum sıcaklık değerinin $60^{\circ} \mathrm{C}$ ve $\mathrm{pH}$ değerinin de 9.5-11.5 arasında olduğu belirlenmiştir (Gessesse ve Gashe 1997). Başka bir çalışmada ise Marinobacter genusundan bir türe ait proteazın optimum $\mathrm{pH}$ ve sıcaklık değerleri sırasıyla 7 ve $40^{\circ} \mathrm{C}$ olarak bulunmuştur (Fulzele ve ark. 2011). Bir diğer çalışmada da Geziwo Qinhuangdao denizinden izole edilen bir bakteri türünün ürettiği proteaz enziminin optimum çalışma sıcaklığ $60^{\circ} \mathrm{C}$ ve $\mathrm{pH}$ değeri ise 10 olarak belirlenmiştir (Cui ve ark. 2015). Hint Okyanusu'ndan izole edilen Microbacterium genusuna ait bir türden elde edilen proteaz enziminin optimum $\mathrm{pH}$ ve sicaklık değerleri ise sırasıyla 12 ve $60^{\circ} \mathrm{C}$ olarak ölçülmüştür (Saggu ve ark. 2019).

Farklı metal iyonları ve enzim inhibitörlerinin enzim aktivitesi üzerine etkisi Şekil 6'da gösterilmiştir. Denenen kimyasalların çoğu üretilen proteaz enziminin aktivitesi üzerine negatif etki göstermiştir. Özellikle EDTA ve Zn, enzimin bağ 1 aktivitesini $\% 40$ civarlarına kadar düşürmüştür. Ca iyonunun ise enzim aktivitesine pozitif veya negatif bir etki göstermediği ölçüldü. Bunun yanında $\mathrm{Mn}$ iyonunun $10 \mathrm{mM}$ konsantrasyonda üretilen proteaz aktivitesini yaklaşık \%24 olarak arttırdığ gözlemlendi (Şekil 6). Literatürdeki bazı çalışmalarda da Mn iyonunun proteaz aktivitesini arttırıcı etkisinden bahsedilmiştir (Manachini ve ark. 1988; Rahman ve ark. 1994; Ul Qader ve ark. 2017; Kannikan ve ark. 2018). Aksine, Microbacterium ile üretilmiş proteazın $5 \mathrm{mM} \mathrm{MnCl}_{2}$ etkisi altında aktivitesinin \%38 azaldığı ölçülmüştür (Thys ve Brandelli 2006).

Şekil 7'de de görüldüğü üzere $-20^{\circ} \mathrm{C}$ 'de bekletilen enzimin, ilk ölçümden itibaren çok büyük miktarda (\%72) aktivite kaybına uğradığı gözlemlendi. Bu sonucun muhtemel sebebi, donma işlemi sırasında oluşan buz kristallerinin enzimin yapısına ve dolayısıyla aktivitesine zarar vermiş olmasıdır (Cao ve ark. 2003). Bu zararın minimize edilmesi için gliserol gibi kriyoprotektanlar kullanılması uygun olacaktır Bunun yanında 4 ve $25^{\circ} \mathrm{C}^{\prime}$ de bekletilen enzimler ise büyük ölçüde aktivitelerini korudular. Depolama süresinin ilk 1 . haftasında 4 ve $25^{\circ} \mathrm{C}$ 'de bekletilen örneklerle yapılan ölçümlerde enzim aktivitesinin $\% 98$ oranında korunduğu gözlemlendi. Daha sonraki süreçlerde enzim aktivitesindeki düşüş $4^{\circ} \mathrm{C}^{\prime}$ deki örneklerde daha yavaş olduğu görüldü. $\mathrm{Bu}$ nedenle sıv1 formdaki enzimin 1 haftadan daha kısa süreli depolanması durumunda maliyetin azaltılması yönünden $25^{\circ} \mathrm{C}$ koşulunun tercih edilebileceği kaydedildi. Depolamanın 6. haftasinda $-20,4$ ve $25^{\circ} \mathrm{C}^{\prime} \mathrm{de}$ bekletilen örneklerin bağıl aktiviteleri sırasılla $\% 27, \% 92$ ve $\% 73$ olarak ölçüldü. Literatürde de, tuzlu ortamlardan izole edilen mikroorganizmalarca üretilmiş enzimlerin oda sıcaklığında uzun süre stabil olduğu belirtilmiştir (Fulzele ve ark. 2011).

\section{Sonuç}

Yapılan çalışmada, sucul ortamdan izole edilen mikroorganizmaların aynı örnekten izole edilseler dahi farklı değerlikte proteaz üretkenliklerine sahip oldukları gösterildi. En üretken izolat ile yapılan çalkalamalı flask üretimlerinde en yüksek enzim aktivitesi $166 \mathrm{U} \mathrm{ml}^{-1}$, enzimin optimum $\mathrm{pH}$ ve sıcaklık değerleri ise sırasıyla 8 ve $35^{\circ} \mathrm{C}$ olarak ölçüldü. Literatürdeki çalışmalarla karşılaştırıldığında da sucul mikrooganizmalarla üretilen proteazların optimum $\mathrm{pH}$ ve sıcaklık değerlerinin birbirlerinden çok farklı olduğu ve metalik iyonların varlığında enzim aktivitesinin büyük farklıklar gösterdiği kaydedildi. Bu yüzden yapılan bu çalışmanın farklı ortamlardan izole edilen mikroorganizmalar için de denenerek, kullanım amaçlarına ve ortam koşullarına uygun olan proteazların keşfedilmesinin önemi vurgulanmıştır.

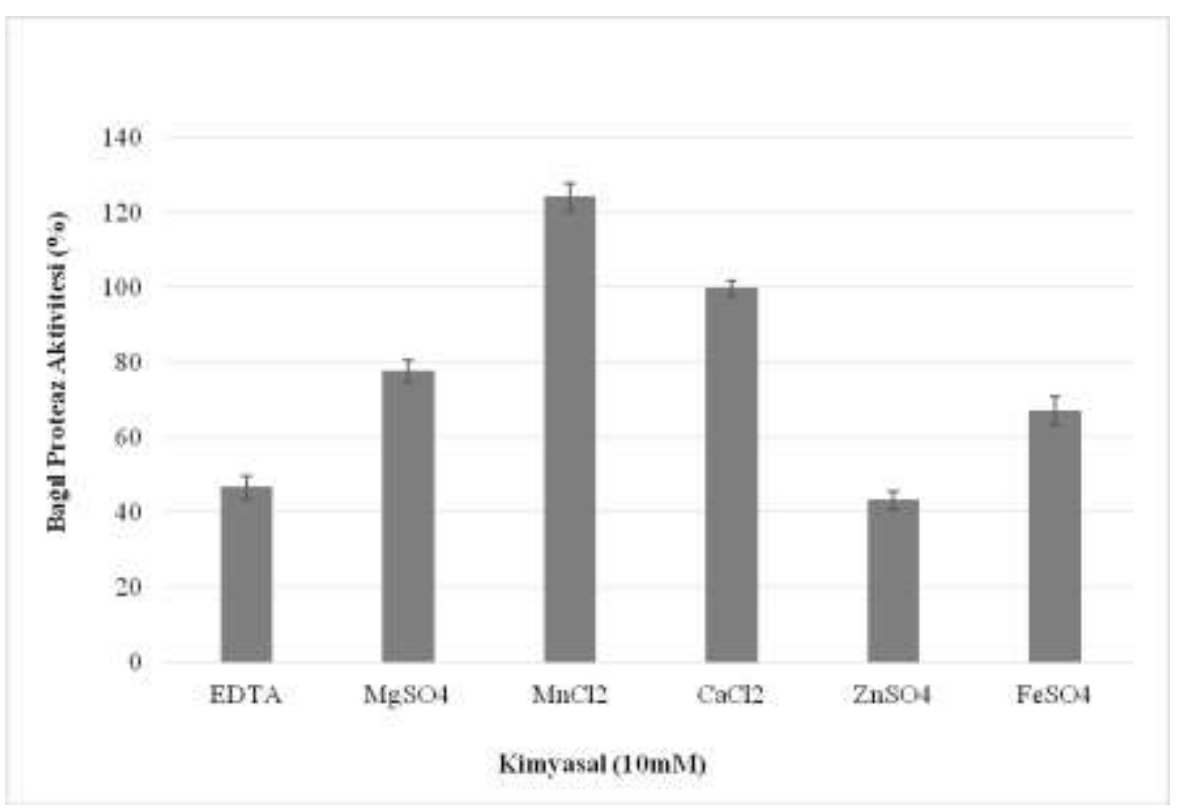

Şekil 6. Seçilmiş kimyasalların proteaz aktivitesine etkileri.

Figure 6. Effect of selected chemicals on protease activity. 


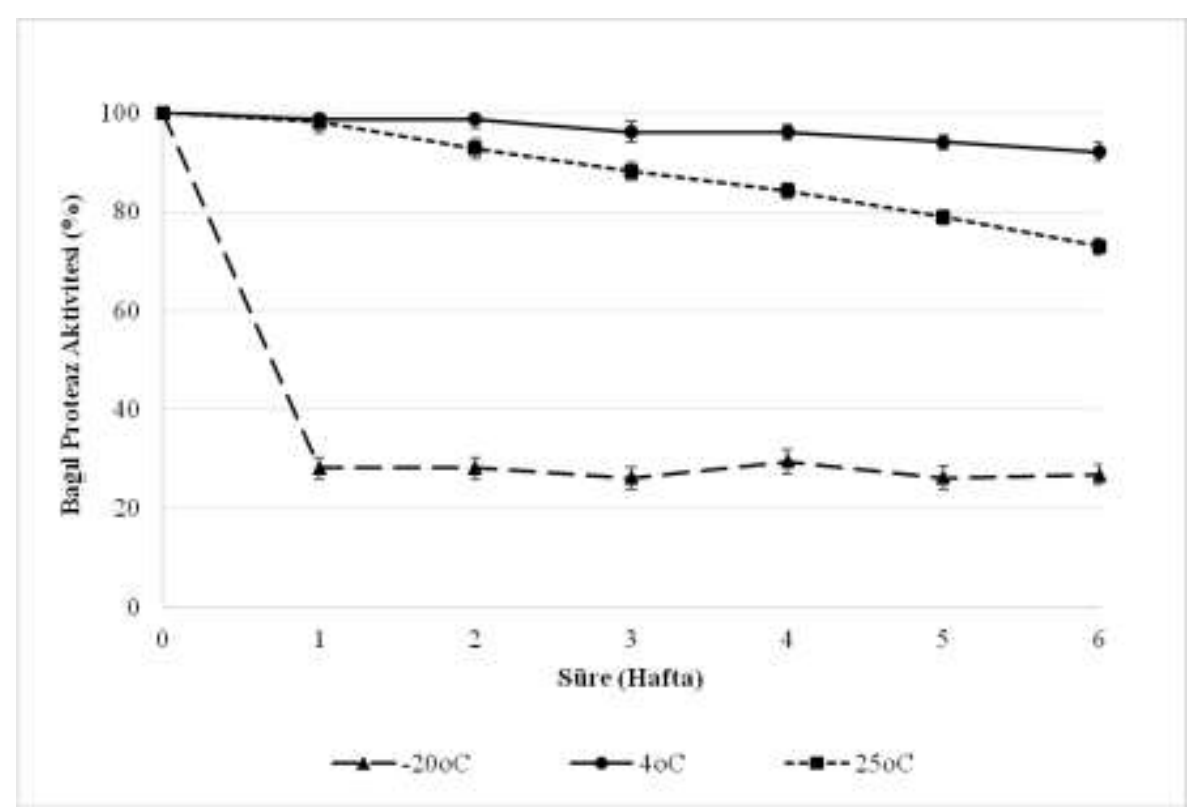

Şekil 7. Depolama sıcaklı̆̆ının proteaz aktivitesine etkisi.

Figure 7. Effect of storage temperature on protease activity.

\section{Teşekkür}

Ege Üniversitesi Biyomühendislik Bölümü öğretim üyelerinden Prof. Dr. Elif Esin Tuna'ya çalışmada kullanılan mikroorganizmaları ve laboratuvar imkânlarını sağladığı için kendisine ve öğrencilerine teşekkür ederim. Ayrıca Prof. Dr. Gaye Öngen Özgen, Doç. Dr. Sait Sargın ve öğrencilerine de destek ve yardımları için teşekkür ederim.

\section{Kaynaklar}

Blommel PG, Becker KJ, Duvnjak P, Fo BG (2007) Enhanced bacterial protein expression during auto-induction obtained by alteration of lac repressor dosage and medium composition. Biotechnology Progress 23(3): 585-598.

Cao EH, Chen YH, Cui ZF, Foster PR (2003) Effect of freezing and thawing rates on denaturation of proteins in aqueous solutions. Biotechnology and Bioengineering 82(6): 684-690.

Cui HX, Wang LP, Yu Y (2015) Production and characterization of alkaline protease from a high yielding and moderately halophilic strain of SD11 marine bacteria. Journal of Chemistry Doi: $10.1155 / 2015 / 798304$.

Fulzele R, DeSa E, Yadav A, Shouche Y, Bhadekar R (2011) Characterization of novel extracellular protease produced by marine bacterial isolate from the Indian Ocean. Brazilian Journal of Microbiology 42(4): 1364-1373.

Gessesse A, Gashe BA (1997) Production of alkaline protease by an alkaliphilic bacteria isolated from an alkaline soda lake. Biotechnology Letters 19(5): 479-481.

Kannikan V, Arumugam P, Rebecca J (2018) Optimization of protease enzyme production by marine actinomycetes. International Journal of Pharma and Bio Sciences 8(3): 188-194.

Manachini PL, Fortina MG, Parini C (1988) Thermostable alkaline protease produced by Bacillus thermoruber - a new species of Bacillus. Applied Microbiology and Biotechnology 28(4): 409-413.

Pilanee V, Taweesiri M, Waraporn A (2008) Silk degumming solution as substrate for microbial protease production. Journal of Biotechnology 136(3): 543-551.

Rahman RNZA, Razak CN, Ampon K, Basri M, Zin WM, Yunus W, Salleh AB (1994) Purification and characterization of a heat-stable alkaline protease from Bacillus stearothermophilus F1. Applied Microbiology and Biotechnology 40(6): 822-827.

Razzaq A, Shamsi S, Ali A, Ali Q, Sajjad M, Malik A, Ashraf M (2019) Microbial proteases applications. Frontiers in Bioengineering and Biotechnology 7: 110.

Saggu SK, Jha G, Mishra PC (2019) Enzymatic degradation of biofilm by metalloprotease from Microbacterium sp. SKS10. Frontiers in Bioengineering and Biotechnology 7: 192.

Sharma KM, Kumar R, Panwar S, Kumar A (2017) Microbial alkaline proteases: Optimization of production parameters and their properties. Journal of Genetic Engineering and Biotechnology 15(1): 115-126.

Thys RCS, Brandelli A (2006) Purification and properties of a keratinolytic metalloprotease from Microbacterium sp. Journal of Applied Microbiology 101(6): 1259-1268.

Ul Qader SA, Sattar H, Aman A (2017) Effect of metal ions, solvents and surfactants on the activity of protease from Aspergillus niger KIBGE-IB36. Journal of Basic \& Applied Sciences 13: 491-495.

Zhang XY, Han XX, Chen XL, Dang HY, Xie BB, Qin QL, Shi M, Zhou BC, Zhang YZ (2015) Diversity of cultivable proteaseproducing bacteria in sediments of Jiaozhou Bay, China. Frontiers in Microbiology 6: 1021. 